\title{
Editorial \\ Electrocatalysts for Energy Conversion and Storage Devices
}

\author{
Vincenzo Baglio
}

check for

updates

Citation: Baglio, V. Electrocatalysts for Energy Conversion and Storage Devices. Catalysts 2021, 11, 1491. https://doi.org/10.3390/catal 11121491

Received: 25 November 2021 Accepted: 5 December 2021 Published: 6 December 2021

Publisher's Note: MDPI stays neutral with regard to jurisdictional claims in published maps and institutional affiliations.

Copyright: (C) 2021 by the author. Licensee MDPI, Basel, Switzerland. This article is an open access article distributed under the terms and conditions of the Creative Commons Attribution (CC BY) license (https:/ / creativecommons.org/licenses/by/ $4.0 /)$.
Institute for Advanced Energy Technologies "Nicola Giordano", CNR-ITAE, Via Salita S. Lucia Sopra Contesse 5, 98126 Messina, Italy; vincenzo.baglio@itae.cnr.it

\section{Introduction}

Energy's efficient conversion and storage are closely correlated to the development of electrochemical energy technologies, such as fuel cells, batteries, electrolyzers, etc. Such devices are claimed to dominate the future sustainable energy economy. Yet, the practical efficiencies must be boosted before many of the aforementioned technologies become viable for large-scale use. In particular, more active, stable, and economically feasible catalysts must be developed for the electrocatalytic processes occurring at practical electrodes of the cells. In this context, the research and development of efficient catalysts are vital to reaching this target. This Special Issue is intended to present and discuss the most recent advances and developments in heterogeneous catalysis for application in electrochemical energy conversion and storage devices.

\section{This Special Issue}

This Special Issue includes 13 high-quality, original articles related to advances in electrocatalysts/electrode development for energy conversion and storage devices or their physicochemical/electrochemical characterization. Most of these papers deal with fuel cell electrocatalysts, mainly addressing the oxygen reduction reaction (ORR) process. Shen et al. [1] explored self-supported Fe-N-C materials, as alternatives to Pt, for the ORR. The catalysts were prepared by the pyrolysis of dual precursors, including EDTA ferric sodium (EDTAFeNa) and melamine (MA), followed by acid-leaching and final annealing. Results showed onset $\left(E_{\text {onset }}\right)$ and half-wave $\left(E_{1 / 2}\right)$ potentials for the ORR of 0.97 and $0.84 \mathrm{~V}$ vs. RHE, respectively, with predominantly a four-electron pathway, similar to the stateof-the-art Pt/C catalyst. Dembinska et al. [2] investigated hybrid systems composed of reduced graphene-oxide-supported platinum and multiwalled carbon-nanotube-supported iridium (both noble metals utilized at low loadings) for the ORR using the rotating ring-disk electrode (RRDE). The addition of iridium produced an enhancement of the electrocatalytic activity, together with a reduction of hydrogen peroxide production. In the work of Mazzapioda et al. [3], a nonstoichiometric calcium titanate $\mathrm{CaTiO}_{3-\delta}(\mathrm{CTO})$ was synthesized and used as an oxygen reduction reaction co-catalyst (together with $\mathrm{Pt} / \mathrm{C}$ ) in direct methanol fuel cells (DMFCs). The presence of the CTO additive promoted the oxygen reduction reaction (ORR) due to the presence of oxygen vacancies as available active sites for oxygen adsorption in the lattice. The increase in power density obtained with the CTO-based electrode, compared with the benchmark $\mathrm{Pt} / \mathrm{C}$, was more than $40 \%$ at $90{ }^{\circ} \mathrm{C}$, reaching a maximum power density close to $120 \mathrm{~mW} \mathrm{~cm} \mathrm{~cm}^{-2}$. Yuan et al. [4] synthesized graphene-like mesoporous carbon sheets with point defects as oxygen reduction/hydrogen evolution bifunctional electrocatalysts by a bubble templating method. They showed excellent ORR performance, with an onset potential of $740 \mathrm{mV}$ and a diffusion-limiting current density of $4.07 \mathrm{~mA} \mathrm{~cm}^{-2}$. The catalyst was also investigated for the hydrogen evolution reaction showing an overpotential of about -453 and $-378 \mathrm{mV}$ at $10 \mathrm{~mA} \mathrm{~cm}^{-2}$ in both alkaline and acidic media.

The ORR is a key process also in solid oxide fuel cells (SOFCs). In this context, Zeng et al. [5] reported a $\mathrm{Zn}$-doped perovskite oxide $\mathrm{Ba}_{0.5} \mathrm{Sr}_{0.5}\left(\mathrm{Co}_{0.8} \mathrm{Fe}_{0.2}\right)_{0.96} \mathrm{Zn}_{0.04} \mathrm{O}_{3-\delta}$ 
(BSCFZ) as the SOFC cathode, which exhibited much higher electrocatalytical activity than $\mathrm{Ba}_{0.5} \mathrm{Sr}_{0.5} \mathrm{Co}_{0.8} \mathrm{Fe}_{0.2} \mathrm{O}_{3-\delta}$ (BSCF) for the ORR. An increase in maximum power density by $35 \%$ in comparison with the BSCF cathode was recorded in a single cell at $750{ }^{\circ} \mathrm{C}$, attributed to a better balance of oxygen vacancies, surface electron transfer, and ionic mobility as promoted by the low-valence $\mathrm{Zn}^{2+}$ doping.

Degn Jensen et al. [6] fabricated thin-film PtxGd electrocatalysts with different stoichiometry using a co-sputter deposition technique. These materials showed great oxygen reduction activity improvement over pure $\mathrm{Pt}$. Co-sputtered $\mathrm{Pt}_{5} \mathrm{Gd}$ and $\mathrm{Pt}_{7.5} \mathrm{Gd}$ thin films were also investigated using $\mathrm{X}$-ray absorption spectroscopy, revealing the importance of forming alloys with specific stoichiometry and supporting the need of forming compressively strained Pt overlayers in order to achieve optimum catalytic performances.

Pushkarev et al. [7] used a polyol method to synthesize $\mathrm{Pt} / \mathrm{C}$ and $\mathrm{Pt} / \mathrm{SnOx} / \mathrm{C}$ catalysts. They were investigated in a rotating disk electrode (RDE) for the ethanol oxidation reaction (EOR). The addition of SnOx to Pt produced a significant increase of the catalyst activity for EOR and ethanol utilization.

Another study regarding catalysts for the ethanol electro-oxidation in alkaline direct ethanol fuel cells was presented by Berretti et al. [8]. Quantifying the oxidation of fuel cell catalysts (in the present case based on Pd nanoparticles) is a task of tremendous importance to design mitigation strategies that extend the service life of catalysts and devices. In their work, the authors successfully demonstrated the application of Fixed Energy X-ray Absorption Voltammetry (FEXRAV) to the quantification of the speciation of palladium in situ, for a given sample with a defined particle distribution.

Recently, polymer electrolyte fuel cells with alkaline anion exchange membranes (AAEMs) have gained tremendous attention due to the advantages of using non-noble metal catalysts. Sebastián et al. [9] examined the preparation procedures for electrodes to be used in anion exchange membrane fuel cells using a commercial Fumasep ${ }^{\circledR}$ FAA-3 membrane and a commercial ionomer of the same nature (Fumion), both from Fumatech $\mathrm{GmbH}$. The anion exchange procedure, the ionomer concentration in the catalytic layer, and also the effect of membrane thickness were analyzed in their paper.

The hydrogen evolution reaction (HER), in the absence and presence of light, on graphite paste $(\mathrm{Gr})$ electrodes including N-octylpyridinium hexafluorophosphate $\left(\mathrm{OPyPF}_{6}\right)$ ionic liquid (IL) as binder and modification with Co-octaethylporphyrin (Co), was investigated by Gidi et al. [10]. Through gas chromatography, it was determined that the graphite paste electrode in the presence of ionic liquid and porphyrin (Gr/IL/Co) presented a high turnover number (TON; 6342 and 6827 in presence of light) in comparison with similar systems reported in the literature.

Lo Vecchio et al. [11] fabricated a tandem photoelectrochemical cell (PEC) consisting of an anionic solid polymer electrolyte membrane (gas separator) clamped between an n-type $\mathrm{Fe}_{2} \mathrm{O}_{3}$ photoanode and a p-type $\mathrm{CuO}$ photocathode. The semiconductors were deposited on fluorine-doped tin oxide (FTO) transparent substrates and the cell was investigated for the water splitting process. Furthermore, a NiFeOx cocatalyst was deposited on the hematite photoanode surface and investigated as a surface catalytic enhancer in order to improve the oxygen evolution reaction (OER) kinetics.

Choi et al. [12] synthesized an activated carbon (AC) with various weight ratios of manganese dioxide (MO) through a simple hydrothermal approach. The composite materials were electrochemically investigated for their potential application in supercapacitors. They exhibited specific capacitance of $60.3 \mathrm{~F} \mathrm{~g}^{-1}$ at $1 \mathrm{~A} \mathrm{~g}^{-1}$, as well as stable cycle performance and $99.6 \%$ capacitance retention over 5000 cycles.

In the last article of this special issue, Yu et al. [13] employed a silver (Ag) foam as a catalytic electrode for the electrochemical reduction of $\mathrm{CO}_{2}$ in aqueous solution to produce different syngas ratios $\left(\mathrm{H}_{2}: \mathrm{CO}\right)$.

Funding: This research received no external funding.

Conflicts of Interest: The author declares no conflict of interest. 


\section{References}

1. Shen, M.; Meng, Z.; Xue, T.; Shen, H.; Yan, X.-H. Electrocatalysis for Oxygen Reduction Reaction on EDTAFeNa and Melamine co-Derived Self-Supported Fe-N-C Materials. Catalysts 2021, 11, 623. [CrossRef]

2. Dembinska, B.; Zlotorowicz, A.; Modzelewska, M.; Miecznikowski, K.; Rutkowska, I.A.; Stobinski, L.; Malolepszy, A.; Krzywiecki, M.; Zak, J.; Negro, E.; et al. Low-Noble-Metal-Loading Hybrid Catalytic System for Oxygen Reduction Utilizing Reduced-Graphene-Oxide-Supported Platinum Aligned with Carbon-Nanotube-Supported Iridium. Catalysts 2020, 10, 689. [CrossRef]

3. Mazzapioda, L.; Lo Vecchio, C.; Aricò, A.S.; Navarra, M.A.; Baglio, V. Performance Improvement in Direct Methanol Fuel Cells by Using $\mathrm{CaTiO}_{3-\delta}$ Additive at the Cathode. Catalysts 2019, 9, 1017. [CrossRef]

4. Yuan, W.; Zhang, F.; Wu, Y.; Chen, X.; Fang, C.; Li, C. Point-Defect-Rich Carbon Sheets as the High-Activity Catalyst Toward Oxygen Reduction and Hydrogen Evolution. Catalysts 2019, 9, 386. [CrossRef]

5. Zeng, Q.; Zhang, X.; Wang, W.; Zhang, D.; Jiang, Y.; Zhou, X.; Lin, B. A Zn-Doped $\mathrm{Ba}_{0.5} \mathrm{Sr}_{0.5} \mathrm{Co}_{0.8} \mathrm{Fe}_{0.2} \mathrm{O}_{3-\delta}$ Perovskite Cathode with Enhanced ORR Catalytic Activity for SOFCs. Catalysts 2020, 10, 235. [CrossRef]

6. Degn Jensen, K.; Filsøe Pedersen, A.; Zamburlini, E.; Erfyl Lester Stephens, I.; Chorkendorff, I.; Escudero-Escribano, M. X-ray Absorption Spectroscopy Investigation of Platinum-Gadolinium Thin Films with Different Stoichiometry for the Oxygen Reduction Reaction. Catalysts 2020, 10, 978. [CrossRef]

7. Pushkarev, A.S.; Pushkareva, I.V.; Ivanova, N.A.; du Preez, S.P.; Bessarabov, D.; Chumakov, R.G.; Stankevich, V.G.; Fateev, V.N.; Evdokimov, A.A.; Grigoriev, S.A. Pt/C and Pt/SnO $/$ /C Catalysts for Ethanol Electrooxidation: Rotating Disk Electrode Study. Catalysts 2019, 9, 271. [CrossRef]

8. Berretti, E.; Giaccherini, A.; Montegrossi, G.; D’Acapito, F.; Di Benedetto, F.; Zafferoni, C.; Puri, A.; Lepore, G.O.; Miller, H.; Giurlani, W.; et al. In-situ Quantification of Nanoparticles Oxidation: A Fixed Energy X-ray Absorption Approach. Catalysts 2019, 9, 659. [CrossRef]

9. Sebastián, D.; Lemes, G.; Luque-Centeno, J.M.; Martínez-Huerta, M.V.; Pardo, J.I.; Lázaro, M.J. Optimization of the Catalytic Layer for Alkaline Fuel Cells Based on Fumatech Membranes and Ionomer. Catalysts 2020, 10, 1353. [CrossRef]

10. Gidi, L.; Honores, J.; Ibarra, J.; Arce, R.; Aguirre, M.J.; Ramírez, G. Study of the Hydrogen Evolution Reaction Using Ionic Liquid/Cobalt Porphyrin Systems as Electro and Photoelectrocatalysts. Catalysts 2020, 10, 239. [CrossRef]

11. Lo Vecchio, C.; Trocino, S.; Campagna Zignani, S.; Baglio, V.; Carbone, A.; Díez García, M.I.; Contreras, M.; Gómez, R.; Aricò, A.S. Enhanced Photoelectrochemical Water Splitting at Hematite Photoanodes by Effect of a NiFe-Oxide co-Catalyst. Catalysts 2020, 10, 525. [CrossRef]

12. Choi, J.R.; Lee, J.W.; Yang, G.; Heo, Y.-J.; Park, S.-J. Activated Carbon/ $\mathrm{MnO}_{2}$ Composites as Electrode for High Performance Supercapacitors. Catalysts 2020, 10, 256. [CrossRef]

13. Yu, Y.; Zhong, N.; Fang, J.; Tang, S.; Ye, X.; He, Z.; Song, S. Comparative Study between Pristine Ag and Ag Foam for Electrochemical Synthesis of Syngas with Carbon Dioxide and Water. Catalysts 2019, 9, 57. [CrossRef] 